\title{
КЛІНІКО-ЛАБОРАТОРНІ ПОКАЗНИКИ У ХВОРИХ, ЯКІ ЛІКУВАЛИСЬ У НВМКЦ «ГВКГ» 3 ПРИВОДУ COVID-19
}

\section{В.І. Трихліб, Т.І. Лисенко, А.О. Єрошенко, О.С. Мартинчик}

\author{
Українська військово-медична академія, м. Київ, Україна
}

Вступ. У статті представлений огляд літератури та результати власного обстеження хворих на нову коронавірусну інфекцію COVID-19 із тяжким перебігом.

Мета дослідження. Встановити особливості лабораторних показників нової коронавірусної хвороби COVID-19 у тяжкохворих, які лікувались у ВРІТ НВМКЦ «ГВКГ» в сезон активності грипу, оскільки раніше нами було встановлено, що негоспітальна пневмонія в даний період року має більш тяжкий перебіг.

Матеріали та методи: оброблені дані 112 медичних карт стаціонарного хворого хворих з тяжким перебігом на нову коронавірусну хворобу COVID-19, які лікувались у ВРIT НВМКЦ «ГВКГ» в період з січня по квітень 2021 р. Хворих розподілили наступним чином: перша група - які одужали, друга - які померли. У всіх пацієнтів була виявлена пневмонія за допомогою рентгенографії органів грудної клітки або ж комп'ютерної томографії. У всіх хворих діагноз був підтверджений за допомогою ПлР у реальному часі на PHК SARS-COV-2. Cтатистична обробка матеріалів дослідження проводилася за допомогою персонального комп'ютера з використанням програми STATISTICA. Було розроблено анкету для введення даних в програму Excel.

Результати. Встановлено, що при надходженні до реанімації у хворих, які одужали та які померли, середні показники рівня лейкоцитів суттєво не відрізнялись (p>0,05). У тих, хто помер, в перші три дні після госпіталізації спостерігались більші коливання рівня лейкоцитів. 34 доби перебування у тих, хто помер, спостерігались вищі як середні показники рівня лейкоцитів, так і їх квартельні відхилення (Q25 та $\left.Q_{75}\right)$. При надходженні кількість лімфоцитів була менше у тих, хто помер, в порівнянні з тими, хто одужав, але в наступні дні у перших спостерігалось подальше їх зниження або збереження на низькому рівні, в той же час у тих, хто одужав, знижені показники тримались практично на тому ж рівні, та з 9 доби перебування у стаціонарі спостерігається їх підвищення ( $<<0,05$ в порівнянні із тими, хто помер). Середній рівень гранулоцитів при надходженні був дещо вище у тих, хто в наступному помре, $і$ в подальшому їх показники збільшуються, в той же час у тих, хто одужає, показники, навпаки вже з 4-ї доби поступово знижуються. $B$ перші три дні після госпіталізації різниці в рівні паличкоядерних нейтрофілів між померлими та одужавшими не було ( $p>0,05)$, в той же час у тих, хто одужав, в наступному спостерігається зменшення їх кількості, а у тих, хто помер, навпаки, відбувається їх зростання. В перші три дні різниці між кількістю тромбоцитів між групами не було, в той же час у тих, хто помер, з 9 доби спостерігаються більш виражені коливання їх кількості. Показники ШОЕ мали більш виражені коливання в перші три дні у тих, хто одужав, і у них в наступному спостерігається зменшення рівня, в той же час у тих, хто помер, після 7 доби реєструється їх значне зростання. Показники АлАТ, АсАТ підвищувались незначно. В перші три дні після госпіталізації у тих, хто помре, спостерігались дещо вищі показники рівня сечовини, в порівнянні із тими, хто одужав (p>0,05). В обох групах хворих в наступні дні спостерігається збільшення рівня сечовини, але у тих, хто помер, було до вищих значень. Також і стосовно показників креатиніну, які були вищі вже на початку госпіталізації і після 7 доби реєструвались більш виражені коливання у померлих, ніж у тих, хто одужав. В обох групах хворих вже одразу після госпіталізації реєструвались підвищені показники рівня глюкози (р>0,05). У тих, хто одужав, спостерігається їх поступове зниження, а у тих, хто помер, після 4 доби їх більше зростання. Одразу після госпіталізації у тих, хто помре, показники СРБ були дещо вищі, але в наступному вже з 4-ї доби у тих, хто помре, реєструється їх подальше зростання, а у тих, хто одужає, навпаки, їх зменшення ( $p<0,05)$.

Висновки. Хворі, які померли від COVID-19, надходили раніше, ніж ті, хто одужали. Під час госпіталізації лабораторні показники можуть не відрізнятись у осіб, які одужають, чи помрають. На початку госпіталізації більш знижені показники рівня лімфоцитів та вищі показники гранулоцитів, сечовини, креатиніну, СРБ можуть свідчити про несприятливий наслідок. Вже після 4 доби перебування у стаціонарі (5-11 доба хвороби) динаміка аналізів може свідчити про подальший перебіг хвороби та можливий наслідок (подальше зниження рівня лімфоцитів, збереження на високому рівні або зростання гранулоцитів, зростання паличкоядерних нейтрофілів, кількості тромбоцитів, ШоЕ, рівня сечовини, креатиніну, СРБ, прокальцитоніну - свідчать про несприятливий наслідок). Необхідно провести подальші дослідження стосовно характеру та терміну ураження нирок, серця, легень, стану мікроциркуляції та їх взаємозв'язку.

Ключові слова: COVID-19, тяжкохворі, лабораторні показники. 
Вступ. В даний час визнано, що навіть після доброякісної початкової стадії у деяких пацієнтів може розвинутись другий більш агресивний період захворювання через розвиток гіперзапалення, що буде потребувати термінової госпіталізації або навіть інтенсивної терапії [1].

На даний час відбувається пошук різноманітних маркерів, які могли би свідчити про розвиток тяжкого перебігу. Результати лабораторних досліджень приводяться в багатьох дослідженнях нової коронавірусної інфекції COVID-19. В більшості дослідженнях повідомлялось про лабораторні показники при госпіталізації, а в ранніх дослідженнях під час епідемії часто не приводились терміни проведення обстеження.

За даними одного із досліджень серед 2361 пацієнтів із COVID-19 лейкоцитоз був виявлений у 18,3\% осіб, лейкопенія - у $28 \%$, а лімфоцитопенія - у 57,5\%. Серед 2200 пацієнтів тромбоцитоз спостерігався у 61\% хворих, а в іншій вибірці (n = 290) СРБ був збільшений у 79\% [2].

Лімфоцитопенія була найпоширенішою лабораторною знахідкою серед пацієнтів, госпіталізованих із підтвердженим COVID-19у $32 \%$ хворих. Найбільша поширеність лімфоцитопенії $(99,1 \%)$ була зареєстрована під час обстеження 225 пацієнтів із середнім віком 50 років [3].

Також виявлено, що у хворих часто реєструвався підвищений рівень СРБ (у 19\% хворих) [3].

Серед інших змін у лабораторних аналізах були наступні: лейкопенія, тромбоцитопенія, зниження альбуміну та підвищені показники ШОЕ, ЛДГ, D-димеру, тропоніну та цитокінів (особливо IL-6), AcAT, АлАТ [3].

За даними дослідження лабораторних аналізів та особливостей перебігу нової коронавірусної інфекції, яке було проведене Ali Pormohammad et al., 2020, встановлено, що у найбільш тяжких пацієнтів рівень тромбоцитів збільшувався у 61\% (95\% ДІ 4178, p <0,001), СРБ - у 79\% (95\% ДІ 65-91, $\mathrm{p}<0,001)$, тоді як показники рівня лімфоцитів мали зниження - у 57,5\% (95\% ДІ 42-79, $\mathrm{p}<0,001)$, табл. 1 [2].

Таблиця 1

Лабораторні особливості для підтверджених пацієнтів з COVID-19

(Ali Pormohammad et al., 2020)

\begin{tabular}{|c|c|c|c|c|c|}
\hline Показники & $\begin{array}{l}\text { одиниці } \\
\text { виміру }\end{array}$ & $\begin{array}{c}\text { Довірчий } \\
\text { інтервал } \\
95 \%\end{array}$ & $\begin{array}{c}\text { Нормальний } \\
\text { діапазон }\end{array}$ & $\begin{array}{l}\text { Загальна } \\
\text { кількість } \\
\text { пацієнтів }\end{array}$ & $\begin{array}{c}\text { Кількість } \\
\text { досліджень }\end{array}$ \\
\hline $\begin{array}{l}\text { Лейкоцити (середнє } \\
\text { значення) }\end{array}$ & $6,2\left(\times 10^{9}\right.$ на л) & $5.3-6.9$ & $3.5-9.5$ & 2961 & 17 \\
\hline Збільшення кіль-ті & $18.3(\%)$ & $6.4-25.6$ & & & \\
\hline Зменшення кіль-ті & $28(\%)$ & $21-33$ & & & \\
\hline Нейтрофіли (середні) & $4,6\left(\times 10^{y}\right.$ на л) & $3.1-5.1$ & $1.8-6.3$ & 1212 & 12 \\
\hline Лімфоцити (середні) & 0,94 (× 109/л) & $0.9-1.06$ & $1.1-3.2$ & 3161 & 18 \\
\hline Зменшення кіль-ті & $57.5(\%)$ & $42-79$ & & & \\
\hline Тромбоцити (середні) & $196,5\left(\times 10^{9} / л\right)$ & $167-205$ & $125-350$ & 2900 & 15 \\
\hline Зменшенні кіль-ті & $13(\%)$ & $5-30$ & & & \\
\hline Збільшення кіль-ті & $61(\%)$ & $41-78$ & & & \\
\hline СРБ (середнє) & 32 (мг / л) & $19.7-46.5$ & $0-0.5$ & 880 & 10 \\
\hline Збільшення рівня & $79(\%)$ & $65-91$ & & & \\
\hline Гемоглобін (середній) & 113 (г / л) & $106-132$ & $130-175$ & 2862 & 12 \\
\hline $\begin{array}{l}\text { ШОЕ (середнє } \\
\text { значення) }\end{array}$ & 44 (мм / год) & $46-57$ & $0-15$ & 320 & 4 \\
\hline Альбумін (середній) & 36,8 (г / л) & $24.5-46$ & \multirow{2}{*}{$40-55$} & \multirow{2}{*}{420} & \multirow{2}{*}{5} \\
\hline Зменшення рівня & $81 \%$ & $72-87$ & & & \\
\hline $\begin{array}{l}\text { Iнтерлейкін-6 } \\
\text { (середній) }\end{array}$ & 8,1 (пг / мл) & $6.8-8.6$ & \multirow[t]{2}{*}{$0.0-7$} & \multirow[t]{2}{*}{509} & \multirow[t]{2}{*}{6} \\
\hline Збільшення рівня & $56 \%$ & $42-61$ & & & \\
\hline ЛДГ (середнє) & 286 & $268-294$ & $120-250$ & 2383 & 12 \\
\hline Збільшення рівня & $69.3(\%)$ & $58-83$ & & & \\
\hline
\end{tabular}


При порівнянні лабораторних показників серед легких та тяжких випадків захворювання, було виявлено, що у пацієнтів 3 тяжким перебігом спостерігаються більш помітні лабораторні відхилення, включаючи нижчий рівень лімфоцитів, вищий рівень маркерів запалення (СРБ, ШОЕ, ЛДГ), Dдимеру, АлАТ, АсАТ. 3 тяжкістю захворювання також пов'язаний вищий рівень цитокінів у сироватці крові та нижчий рівень Тлімфоцитів [3].

Результати іншого лабораторних показників у хворих, надходили до стаціонару, в тому числі і y відділення реанімації представлені в табл. 2 [4]. Автори також встановили, що більшість пацієнтів мали нормальний рівень прокальцитоніну в сироватці при надходженні (прокальцитонін $<0,1 \quad$ нг/мЛ; $27 \quad$ [69\%] пацієнтів). У чотирьох пацієнтів, які лікувались у реанімації, розвинулись вторинні інфекції. У трьох із чотирьох пацієнтів із вторинною інфекцією прокальцитонін перевищував 0,5 нг/мл (0,69 нг/мл, 1,46 нг/мл та 6,48 нг/мл) [4].

Таблиця 2

Лабораторні дані пацієнтів, інфікованих 2019-nCoV під час надходження в лікарню

(Dawei Wang, Bo Hu, Chang Hu et al., 2020)

\begin{tabular}{|c|c|c|c|c|}
\hline Показники & $\begin{array}{c}\text { Усі пацієнти } \\
(n=41)\end{array}$ & $\begin{array}{c}\text { Реанімаційне } \\
\text { відділення, } \\
\text { (n=13) }\end{array}$ & $\begin{array}{c}\text { Амбулаторні хворі } \\
(\mathrm{n}=28)\end{array}$ & $\mathbf{p}$ \\
\hline $\begin{array}{l}\text { Кількість лейкоцитів, × } \\
10^{9} / \text { л }\end{array}$ & $6,2(4,-10)$, & $11,3(5,8-12,1)$ & $5,7(3,1-7,6)$ & 0,011 \\
\hline$<4$ & $10 / 40(25 \%)$ & $1 / 13(8 \%)$ & $9 / 27(33 \%)$ & 0,041 \\
\hline $4-10$ & $18 / 40(45 \%)$ & $5 / 13(38 \%)$ & $13 / 27(48 \%)$ & .. \\
\hline$>10$ & $12 / 40(30 \%)$ & $7 / 13(54 \%)$ & $5 / 27(19 \%)$ &.. \\
\hline $\begin{array}{l}\text { Кількість нейтрофілів, × } \\
10^{9} / \text { л }\end{array}$ & $5,0(3,3-8,9)$ & $10,6(5,0-11,8)$ & $4,4(2,0-6,1)$ & 0,00069 \\
\hline $\begin{array}{l}\text { Кількість лімфоцитів, × } \\
10^{9} \text { / л }\end{array}$ & $0,8(0,6-1,1)$ & $0,4(0,2-0,8)$ & $1,0(0,7-1,1)$ & 0,0041 \\
\hline$<1 \cdot 0$ & $26 / 41(63 \%)$ & $11 / 13(85 \%)$ & $15 / 28(54 \%)$ & 0,045 \\
\hline$\geq 1 \cdot 0$ & $15 / 41(37 \%)$ & $2 / 13(15 \%)$ & $13 / 28(46 \%)$ & \\
\hline Гемоглобін, г / л & $126,0(118,0-140,0)$ & $122,0(111,0-128,0)$ & $130,5(120,0-140,0)$ & 0,20 \\
\hline $\begin{array}{l}\text { Кількість тромбоцитів, } \times \\
10^{9} / \text { л }\end{array}$ & $164,5(131,5-263,0)$ & $196,0(165,0-263,0)$ & $149,0(131,0-263,0)$ & 0,45 \\
\hline$<100$ & $2 / 40(5 \%)$ & $1 / 13(8 \%)$ & $1 / 27(4 \%)$ & 0.45 \\
\hline$\geq 100$ & $38 / 40(95 \%)$ & $12 / 13(92 \%)$ & $26 / 27(96 \%)$ & .. \\
\hline Протромбіновий час, с & $11,1(10,1-12,4)$ & $12,2(11,2-13,4)$ & $10,7(9,8-12,1)$ & 0,012 \\
\hline $\begin{array}{l}\text { Час активов. часткового } \\
\text { тромбопластину, с }\end{array}$ & $27,0(24 \cdot 2-34 \cdot 1)$ & $26,2(22,5-33,9)$ & $27,7(24,8-34,1)$ & 0,57 \\
\hline D-димер, мг / л & $0,5(0,3-1,3)$ & $2,4(0,6-14,4)$ & $0,5(0,3-0,8)$ & 0,0042 \\
\hline Альбумін, г / л & $31,4(28,9-36,0)$ & $27,9(26,3-30,9)$ & $34,7(30,2-36,5)$ & 0,00066 \\
\hline АлАТ, Од. / л & $32,0(21,0-50,0)$ & $49,0(29,0-115,0)$ & $27,0(19,5-40,0)$ & 0,038 \\
\hline АсАТ, Од. / л & $34,0(26,0-48,0)$ & $44,0(30,0-70,0)$ & $34,0(24,0-40,5)$ & 0,10 \\
\hline$\leq 40$ & $26 / 41(63 \%)$ & $5 / 13(38 \%)$ & $21 / 28(75 \%)$ & 0,025 \\
\hline$>40$ & $15 / 41(37 \%)$ & $8 / 13(62 \%)$ & $7 / 28(25 \%)$ & .. \\
\hline Заг.білірубін, ммоль / л & $11,7(9,5-13,9)$ & $14,0(11,9-32,9)$ & $10,8(9,4-12,3)$ & 0,011 \\
\hline Калій, ммоль / л & $4,2(3,8-4,8)$ & $4,6(4,0-5,0)$ & $4,1(3,8-4,6)$ & 0,27 \\
\hline Натрій, ммоль / л & $139,0(137,0-140,0)$ & $138,0(137,0-139,0)$ & $139,0(137,5-140,5)$ & 0,26 \\
\hline Креатинін, мкмоль / л & $74,2(57,5-85,7)$ & $79,0(53,1-92,7)$ & $73,3(57,5-84,7)$ & 0,84 \\
\hline$\leq 133$ & $37 / 41(90 \%)$ & $11 / 13(85 \%)$ & $26 / 28(93 \%)$ & 0,42 \\
\hline$>133$ & $4 / 41(10 \%)$ & $2 / 13(15 \%)$ & $2 / 28(7 \%)$ & .. \\
\hline Креатинкіназа, Од. / л & $132,5(62,0-219,0)$ & $132,0(82,0-493,0)$ & $133,0(61,0-189,0)$ & 0,31 \\
\hline$\leq 185$ & $27 / 40(68 \%)$ & $7 / 13(54 \%)$ & $20 / 27(74 \%)$ & 0,21 \\
\hline$>185$ & $13 / 40(33 \%)$ & $6 / 13(46 \%)$ & $7 / 27(26 \%)$ & \\
\hline
\end{tabular}




\begin{tabular}{|c|c|c|c|c|}
\hline Показники & $\begin{array}{c}\text { Усі пацієнти } \\
(\mathrm{n}=\mathbf{4 1})\end{array}$ & $\begin{array}{c}\text { Реанімаційне } \\
\text { відділення, } \\
\text { (n= 13) }\end{array}$ & $\begin{array}{c}\text { Амбулаторні хворі } \\
\text { (n= 28) }\end{array}$ & p \\
\hline $\begin{array}{l}\text { Лактатдегідрогеназа, } \\
\text { Од. / л }\end{array}$ & $286,0(242,0-408,0)$ & $400,0(323,0-578,0)$ & $281,0(233,0-357,0)$ & 0,0044 \\
\hline$\leq 245$ & $11 / 40(28 \%)$ & $1 / 13(8 \%)$ & $10 / 27(37 \%)$ & 0,036 \\
\hline$>245$ & $29 / 40(73 \%)$ & $12 / 13(92 \%)$ & $17 / 27(63 \%)$ & .. \\
\hline $\begin{array}{l}\text { Гіперчутливий тропонін } \\
\text { I, пг / мл }\end{array}$ & $3,4(1,1-9,1)$ & $3,3(3,0-163,0)$ & $3,5(0,7-5,4)$ & 0,075 \\
\hline $\begin{array}{l}>28 \text { (99-й } \\
\text { процентиль) }\end{array}$ & $5 / 41(12 \%)$ & $4 / 13(31 \%)$ & $1 / 28(4 \%)$ & 0,017 \\
\hline Прокальцитонін, нг / мл & $0,1(0,1-0,1)$ & $0,1(0,1-0,4)$ & $0,1(0,1-0,1)$ & 0,031 \\
\hline$<0,1$ & $27 / 39(69 \%)$ & $6 / 12(50 \%)$ & $21 / 27(78 \%)$ & 0.029 \\
\hline$\geq 0,1$ до $<0,25$ & $7 / 39(18 \%)$ & $3 / 12(25 \%)$ & $4 / 27(15 \%)$ &.. \\
\hline$\geq 0,25$ до $<0,5$ & $2 / 39(5 \%)$ & $0 / 12$ & $2 / 27(7 \%)$ & .. \\
\hline$\geq 0,5$ & $3 / 39(8 \%)$ & $3 / 12(25 \%)$ & $0 / 27$ & .. \\
\hline $\begin{array}{l}\text { Рентген. двобічне } \\
\text { ураження легень }\end{array}$ & 40/41 (98\%) & $13 / 13(100 \%)$ & $27 / 28(96 \%)$ & 0,68 \\
\hline
\end{tabular}

За даними Roberto Assandri et al., 2020, прості базові лабораторні біомаркери чітко пов'язані з клінічними ознаками. Як показали дослідження авторів, кількість лейкоцитів нижче $10 \times 10^{9} /$ л реєструвалась у $82 \%$ пацієнтів, кількість нейтрофілів нижче $10 \times 10^{9}$ /л у 83,4\% осіб та кількість лімфоцитів нижче $1 \times 10^{9} /$ л у 55,6\%. Крім того, значення Среактивного білка, АсАТ та ЛДГ були підвищені у більшості пацієнтів, особливо серед пацієнтів 3 найтяжчим перебігом та найгіршим наслідком. Співвідношення нейтрофілів / лімфоцитів також було вищим у пацієнтів 3 більш тяжким перебігом. Встановлено, що СРБ швидко збільшується після початку запалення. Автори встановили, що СРБ>7 мг/дл може ідентифікувати осіб 3 тяжким перебігом захворюванням [1].

Автори Roberto Assandri et al., 2020, запропонували використовувати декілька показників (кількість лімфоцитів, співвідношення L / N, рівень $\mathrm{SaO}_{2}$ та СРБ) для оцінки ступеня тяжкості COVID-19 у лікарні швидкої допомоги [1].

Pormohammad A. et al., 2020, також запропонували використовувати показники: лімфопенія, вік, багатодольова інфільтрація, анамнез куріння, гіпертонія та бактеріальна ко-інфекція - як фактори ризику летального наслідку [2].

3 урахуванням того, що на клініколабораторні прояви респіраторних інфекцій, в тому числі і на коронавірусну інфекцію мають вплив супутні інфекції, структура яких змінюється в залежності від сезону року метою нашого дослідження було встановити особливості лабораторних показників нової коронавірусної хвороби COVID-19 у тяжкохворих, які лікувались у ВРІТ НВМКЦ «ГВКГ» в сезон активності грипу, оскільки раніше нами було встановлено, що негоспітальна пневмонія в даний період року має більш тяжкий перебіг.

Матеріали та методи дослідження. Оброблені дані 112 медичних карт стаціонарного хворого, хворих 3 тяжким перебігом на нову коронавірусну хворобу COVID-19, які лікувались у BPIT НВМКЦ «ГВКГ» в період з січня по квітень 2021p. Віковий розподіл всіх хворих, які лікувались у ВРІТ НВМКЦ «ГВКГ» наведено в табл. 3.

Віковий розподіл всіх хворих, які лікувались у ВРІТ НВМКЦ «ГВКГ»

\begin{tabular}{|c|c|c|c|}
\hline Вік хворих (років) & Хворі, які одужали & Хворі, які померли & Всі хворі \\
\hline $20-29$ & $1(1,25 \%)$ & 0 & $1(0,89 \%)$ \\
\hline $30-39$ & $6(7,5 \%)$ & 0 & $6(5,36 \%)$ \\
\hline $40-49$ & $20(25 \%)$ & 0 & $20(17,86 \%)$ \\
\hline $50-59$ & $17(21,25 \%)$ & $1(3,12 \%)$ & $18(16,07 \%)$ \\
\hline $60-69$ & $13(16,25 \%)$ & $4(12,5 \%)$ & $17(15,17 \%)$ \\
\hline $70-79$ & $14(17,5 \%)$ & $13(40,62 \%)$ & $27(24,1 \%)$ \\
\hline $80-89$ & $8(10 \%)$ & $13(40,62 \%)$ & $21(18,75 \%)$ \\
\hline$>=90$ & $1(1,25 \%)$ & $1(3,13 \%)$ & $2(1,79 \%)$ \\
\hline
\end{tabular}

1 - 20-29 років, 2 - 30-39 років, 3 - 40-49 років, 4 - 50-59 років, 4 - 60-69 років,

5 - 70-79 років, 6 - 80-89 років, 7 - 90 і більше років. 
Хворих розподілили наступним чином: перша група - які одужали, друга - які померли.

У всіх пацієнтів була виявлена пневмонія за допомогою рентгенографії органів грудної клітки або ж комп'ютерної томографії.

У всіх хворих діагноз був підтверджений за допомогою ПЛР у реальному часі на РНК SARS-COV-2.

Статистична обробка матеріалів дослідження проводилася за допомогою персонального комп'ютера з використанням програми STATISTICA. Було розроблено анкету для введення даних в програму Excel.

Результати дослідження та їх обговорення. Хворі, які в наступному одужали, надходили у ВРІТ на $\mathrm{Me}=8$ добу $\left(Q_{25}=5, Q_{75}=10\right), \min =0, \max =17$ добу. Пацієнти, які в наступному померли, надходили у ВРIT на $\mathrm{Me}=5$ добу $\left(\mathrm{Q}_{25}=1,5, \mathrm{Q}_{75}=7\right)$, $\min =0, \max =17$ добу.

Вважається, що одним із проявів бактеріальної інфекції $\epsilon$ наявність лейкоцитозу, тому ми провели дослідження 3 виявлення взаємозв'язку наявності змін у рівні лейкоцитів та наслідками хвороби в залежності від віку хворих. Встановлено, що у хворих з лейкоцитозом в перші три дні після госпіталізації були наступні наслідки: 8 (28,6\%) померло, 20 (71,4\%) одужало; у хворих 3 нормоцитозом - 18 (25,7\%) померло, 52 $(74,3 \%)$ одужало, з лейкопенією - 5 (41,7\%) померло, 7 (58,3\%) одужало.

Таблиця 4

Наслідки нової коронавірусної інфекції COVID-19 в залежності від віку та змін у рівні лейкоцитів

\begin{tabular}{|c|c|c|c|c|c|c|}
\hline \multirow{2}{*}{$\begin{array}{c}\text { Вікова } \\
\text { група }\end{array}$} & \multicolumn{2}{|c|}{ Лейкоцитоз } & \multicolumn{2}{|c|}{ Нормоцитоз } & \multicolumn{2}{|c|}{ Лейкопенія } \\
\hline & одужав & Помер & Одужав & Помер & Одужав & Помер \\
\hline 1 & 0 & 0 & 0 & 0 & $1(100 \%)$ & 0 \\
\hline 2 & $1(100 \%)$ & 0 & $4(100 \%)$ & 0 & $1(100 \%)$ & 0 \\
\hline 3 & $5(100 \%)$ & 0 & $15(100 \%)$ & 0 & 0 & 0 \\
\hline 4 & $6(100 \%)$ & 0 & $8(88,9 \%)$ & $1(11,1 \%)$ & $2(100 \%)$ & 0 \\
\hline 5 & $4(80 \%)$ & $1(20 \%)$ & $7(77,8 \%)$ & $2(22,2 \%)$ & $2(66,7 \%)$ & $1(33,3 \%)$ \\
\hline 6 & $3(50 \%)$ & $3(50 \%)$ & $11(64,7 \%)$ & $6(35,3 \%)$ & 0 & $3(100 \%)$ \\
\hline 7 & $1(20 \%)$ & $4(80 \%)$ & $7(46,6 \%)$ & $8(53,3 \%)$ & 0 & $1(100 \%)$ \\
\hline 8 & 0 & 0 & 0 & $1(100 \%)$ & $1(100 \%)$ & 0 \\
\hline
\end{tabular}

Далі ми провели дослідження стосовно динаміки різних лабораторних показників, які спроможні виконувати госпіталі. 3 наступних рисунків видно, що при надходженні до реанімації у хворих, які одужали та які померли, середні показники рівня лейкоцитів суттєво не відрізнялись ( $>>0,05)$, в той же час у тих, хто помер, вже в перші три дні після госпіталізації спостерігались більші коливання їх показників. 3 часом вже з 4 доби перебування у тих, хто помер, спостерігались вищі як середні показники рівня лейкоцитів, так і їх квартельні відхилення $\left(Q_{25}\right.$ та $\left.Q_{75}\right)$. Вже при надходженні кількість лімфоцитів була менше у тих, хто помер, в порівнянні з тими, хто одужав, але в наступні дні у перших спостерігалось подальше ix зниження або збереження на низькому рівні, в той же час у тих, хто одужав, знижені показники тримались практично на тому ж рівні та 39 доби перебування у стаціонарі спостерігається їх підвищення ( $<<0,05$ в порівнянні із тими, хто помер, рис. 1). Середній рівень гранулоцитів (рис. 1) при надходженні був дещо вище у тих, хто в наступному помре, і в подальшому їх показники збільшуються, в той же час у тих, хто одужає, показники навпаки вже з 4-ї доби поступово знижуються.

В перші три дні після госпіталізації різниці в рівні паличкоядерних нейтрофілів між померлими та одужавшими не було $(\mathrm{p}>0,05)$, в той же час у тих, хто одужав, в наступному спостерігається зменшення їх кількості, а у тих, хто помер, навпаки відбувається зростання (рис. 1).

Також в перші три дні різниці між кількістю тромбоцитів між групами не було, в той же час у тих, хто помер, 39 доби спостерігаються більш виражені коливання їхньої кількості (рис. 2).

Показники ШОЕ (рис. 2) мали більш виражені коливання в перші три дні у тих, хто одужав, і у них в наступному спостерігається зменшення рівня, в той же час у тих, хто помер, після 7 доби реєструється їхнє значне зростання. 


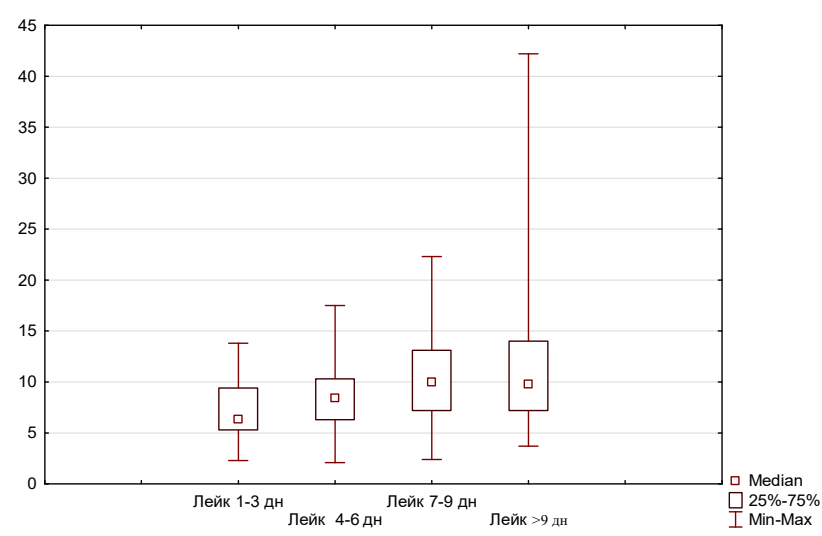

Динаміка рівня лейкоцитів у хворих, які одужали $\left(\times 10^{9} / \Omega\right)$

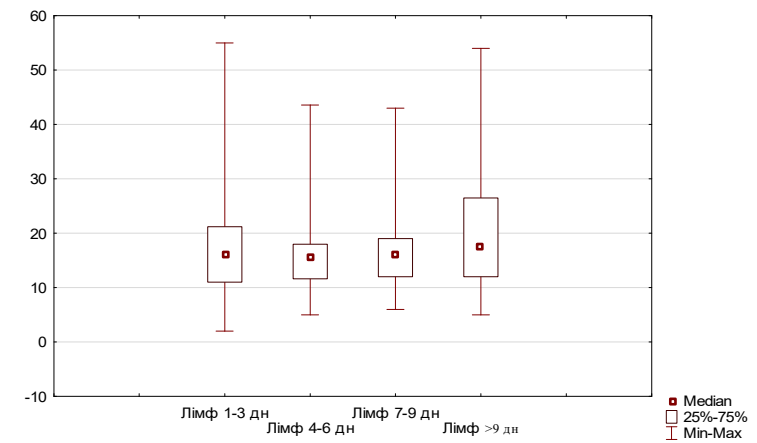

Динаміка рівня лімфоцитів у хворих, які одужали (\%)

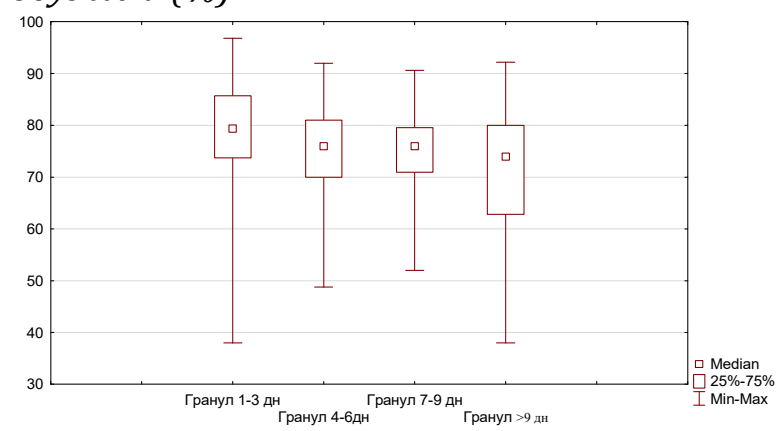

Динаміка рівня гранулоцитів у осіб, які одужали (\%)

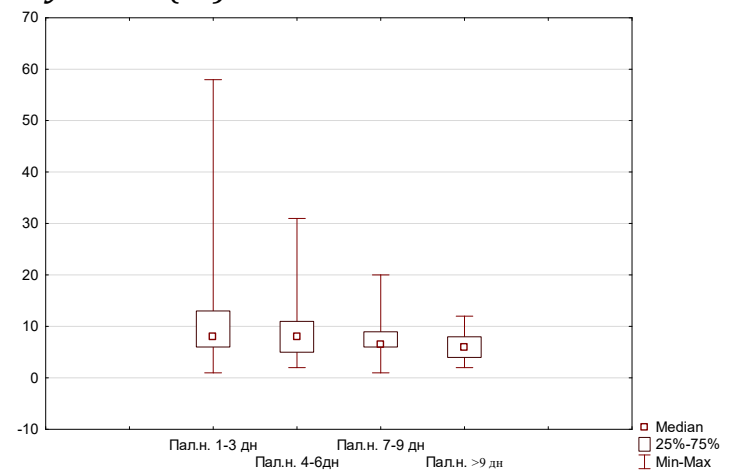

Динаміка рівня пал.нейтрофілів у хворих, які одужали (\%)

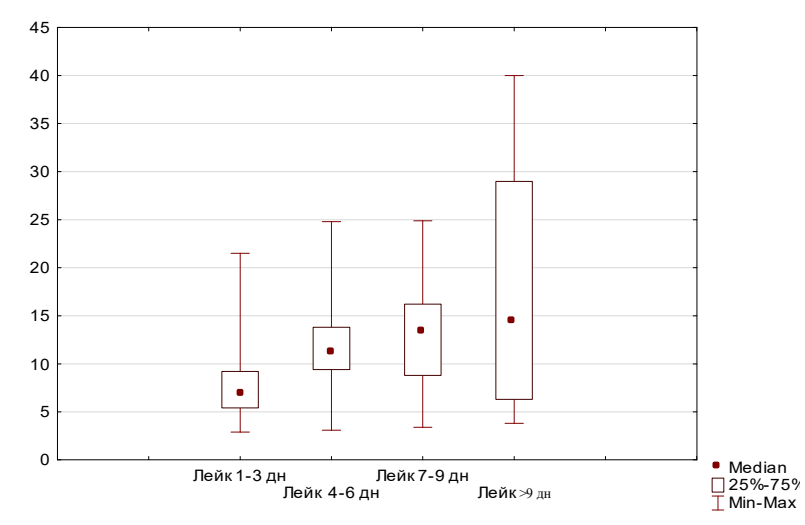

Динаміка рівня лейкоцитів у хворих, які померли $\left(\times 10^{9} / \Omega\right)$

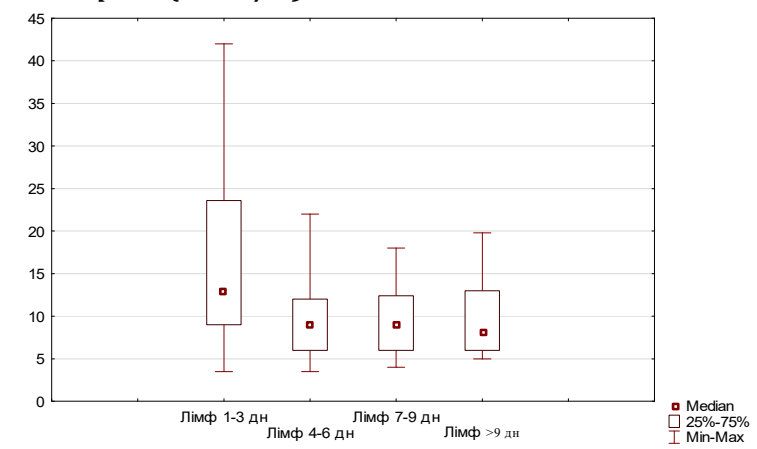

Динаміка рівня лімфоцитів у хворих, які померли (\%)

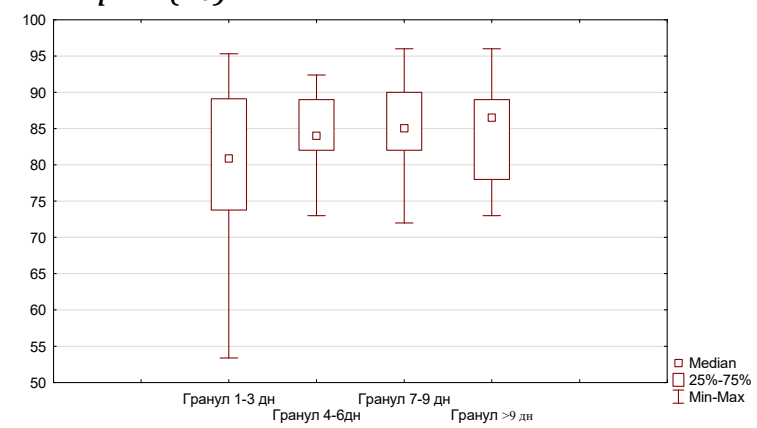

Динаміка рівня гранулоцитів у хворих, які померли (\%)

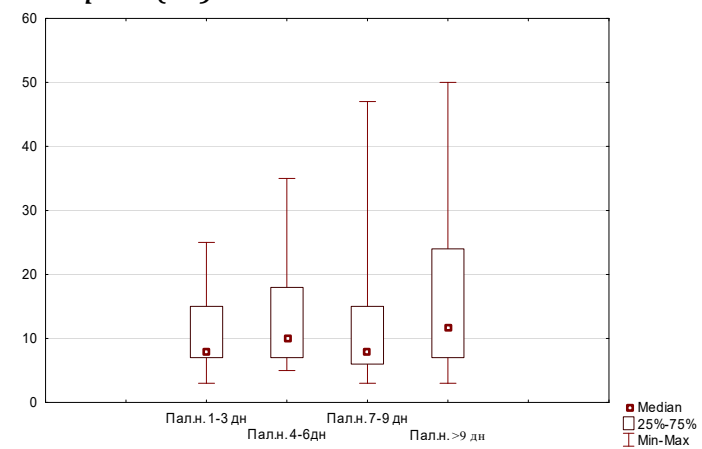

Динаміка рівня пал.нейтрофілів у хворих, які померли (\%)

Рисунок 1. Динаміка рівня показників аналізу крові у хворих, які одужали або померли 


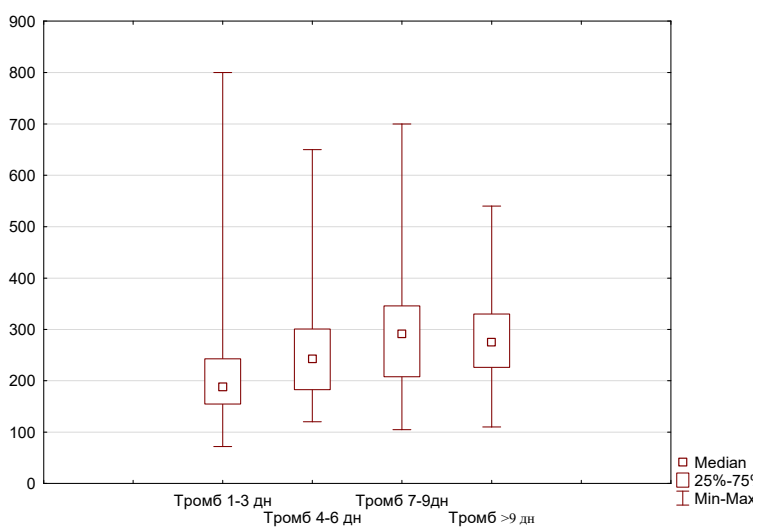

Динаміка рівня тробоцитів у хворих, які одужали $\left(\times 10^{9} / \Omega\right)$

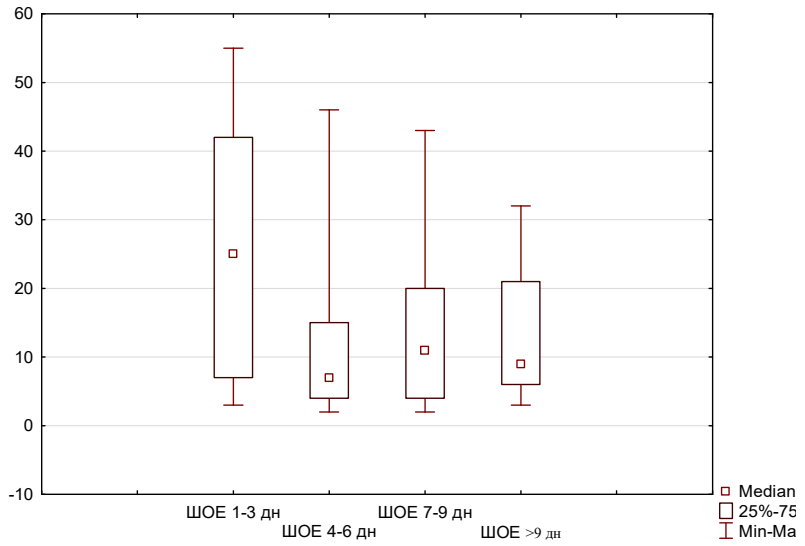

Динаміка рівня ШОЕ у осіб, які одужали $(\mathrm{MM} / 2)$

Рисунок 2. Динаміка рівня показників тромбоцитів та рівня ШОЕ у хворих, які одужали або померли

3 наступних рисунків видно, що в обох групах хворих в середньому спостерігалось незначне збільшення рівня АлАТ (різниці не було, p<0,05), але в перші 6 днів у тих, хто одужав, спостерігались значні коливання їх рівня, а у тих, хто помер, в період із 4 по 9 добу.

Середні значення рівня АсАТ (рис. 3) також між групами не відрізнялись $(\mathrm{p}<0,05)$, в той же час у тих, хто одужав, значні коливання спостерігались в перші дні після госпіталізації, а у тих, хто помер, в більш пізній період. Вже в перші три дні після госпіталізації у тих, хто помре, спостерігались дещо вищі показники рівня сечовини, в порівнянні із тими, хто одужав, $(p>0,05)$ (рис. 3). В обох групах хворих в наступні дні спостерігається збільшення рівня сечовини, але у тих, хто помре, до більш високих значень. Також і стосовно показників креатиніну, які були більше вже на початку госпіталізації і після 7 доби реєструвались більш виражені коливання у померлих, ніж у тих, хто одужав.

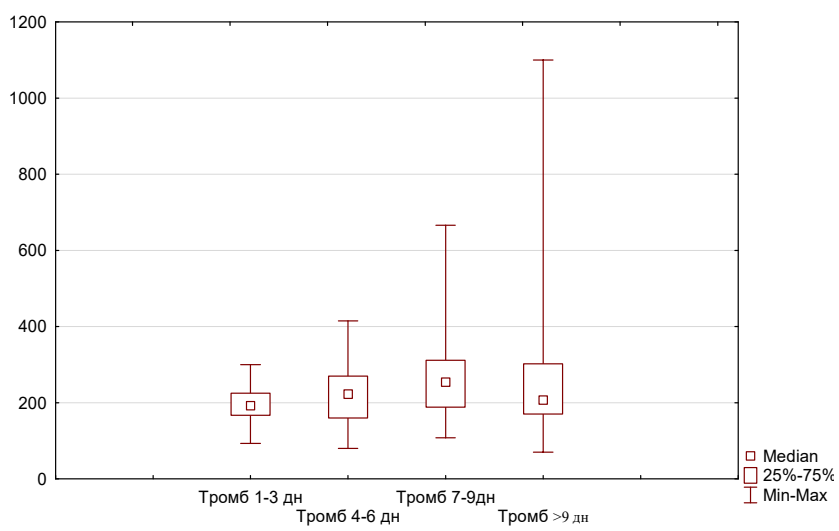

Динаміка рівня тромбоцитів у хворих, які померли $\left(\times 10^{9} / \Omega\right)$

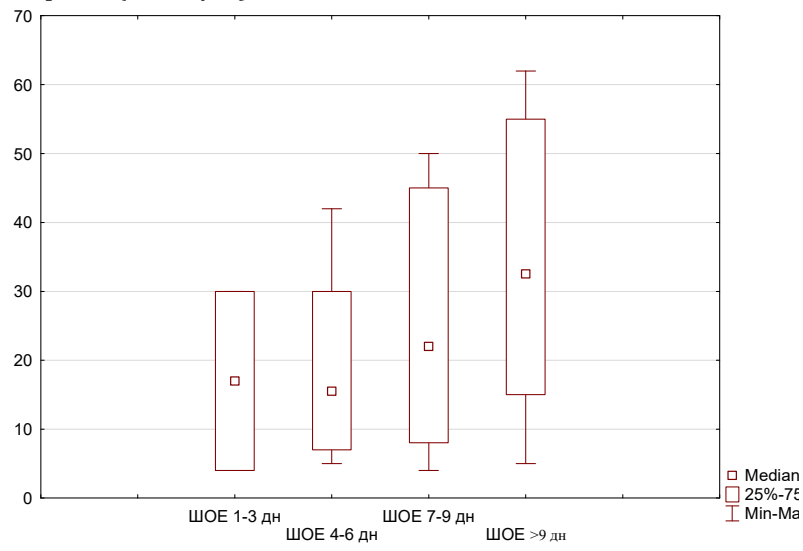

Динаміка рівня ШОЕ у осіб, які померли $(M M / 2)$
В обох групах хворих вже одразу після госпіталізації реєструвались підвищені показники рівня глюкози (p>0,05), в той же час у тих, хто одужав, спостерігається їх поступове зниження, а у тих, хто помер, після 4 доби їх більше зростання (рис. 4).

3 рис. 4 видно, що вже одразу після госпіталізації у тих, хто помре, показники СРБ були дещо більше (p>0,05), але в наступному вже з 4-ї доби у тих, хто помре, реєструється їх подальше зростання, а у тих, хто одужає, навпаки іх зменшення $(\mathrm{p}<0,05)$.

Показники рівня феритину були значно збільшені у тих, хто одужає, вже з початку госпіталізації і в подальшому відбувається їх зниження (рис. 4), на жаль, показники феритину у хворих, які помруть були дослідженні тільки у декількох хворих і простежити їх динаміку не вдалось (рис. 4). У осіб, які в наступному помруть, вже з початку госпіталізації і протягом лікування реєструвались більш значні коливання показників КФК, в порівнянні із тими, хто 
одужає, у останніх значні коливання спостерігались протягом тижня після

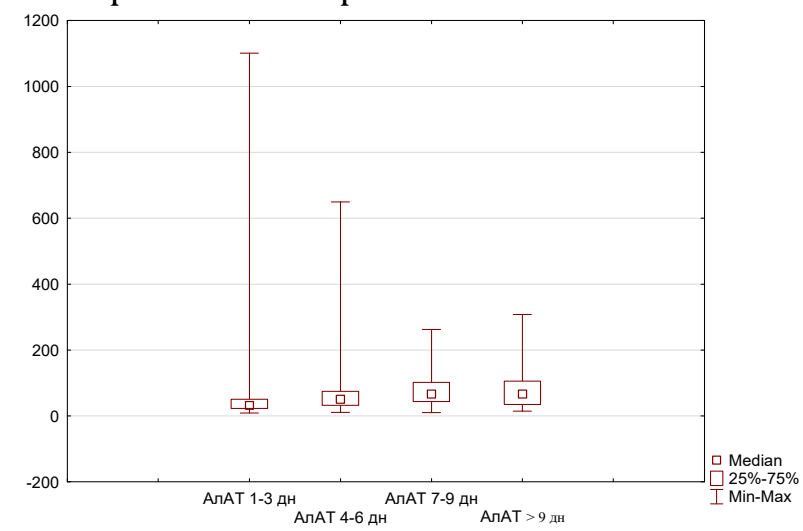

Динаміка рівня АлАТ у хворих, які одужали (Од/л)

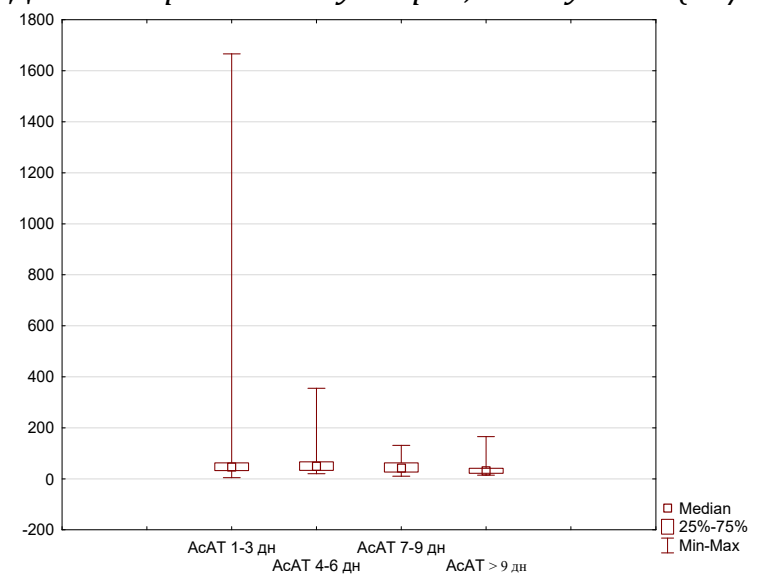

Динаміка рівня АсАТ у хворих, які одужали $(O \partial / \Omega)$

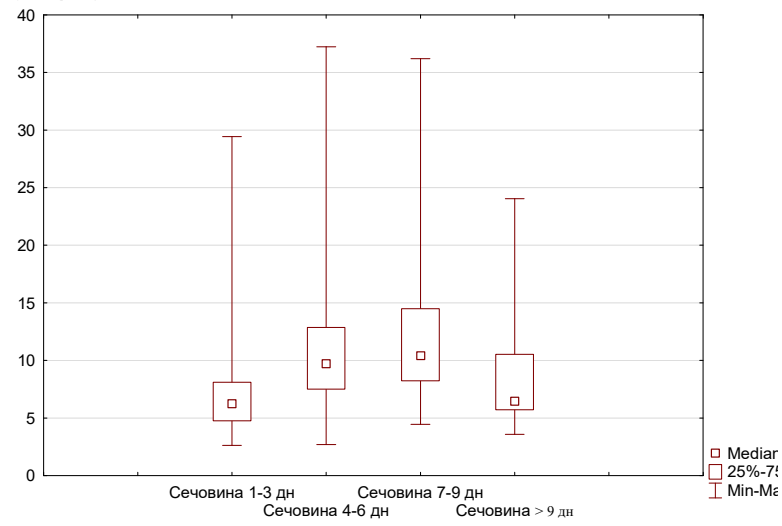

Динаміка рівня сечовини у хворих, які одужали (ммоль/л)

Рисунок 3. Динаміка рівня окремих біохімічних показників крові у хворих, які одужали або померли

Показники КФК-МВ у тих, хто помре, збільшуються вже 34 доби госпіталізації і реєструвались значні коливання їх показників, в порівнянні із тими, хто одужає $(\mathrm{p}<0,05)$ (рис. 5). Середній рівень ЛДГ (рис. 5) в перші три дні після госпіталізації не відрізнявся у двох госпіталізації і значно зменшуються після 9 доби (рис. 5).

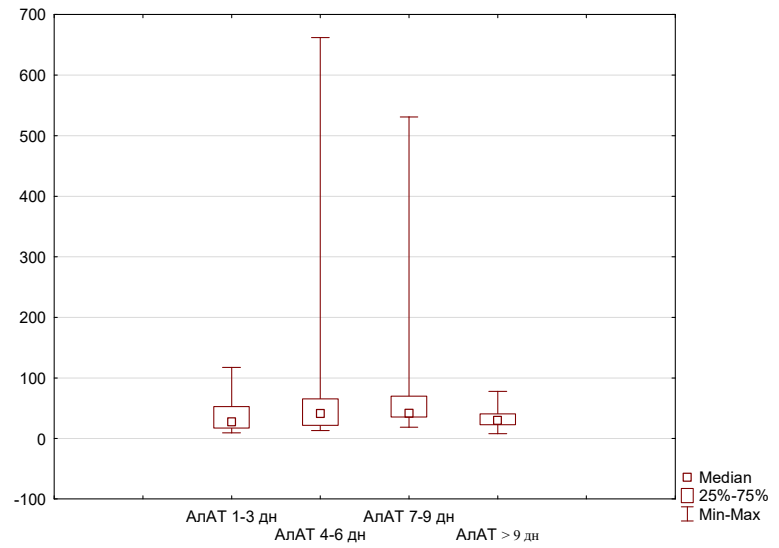

Динаміка рівня АлАТ у хворих, які померли (Од/л)

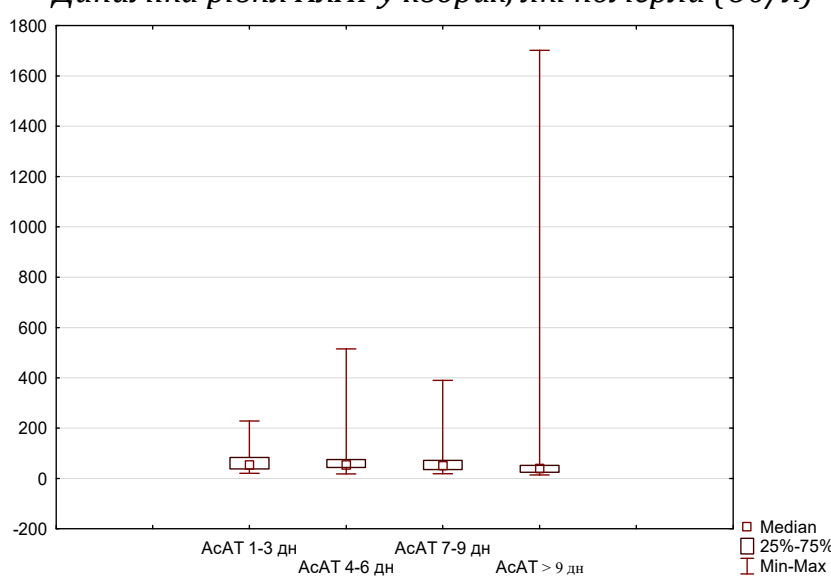

Динаміка рівня АсАТ у хворих, які померли (Од/л)

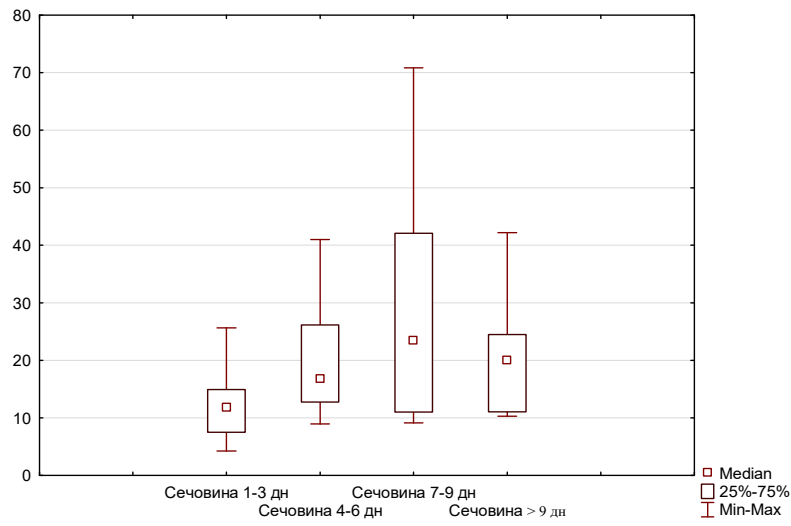

Динаміка рівня сечовини у хворих, які померли (ммоль/л) групах (p>0,05), у тих, хто одужав, на початку спостерігались значні коливання показників i в подальшому спостерігалось їх поступове зниження, 34 доби у хворих, які померли, показники були декілька більше. 


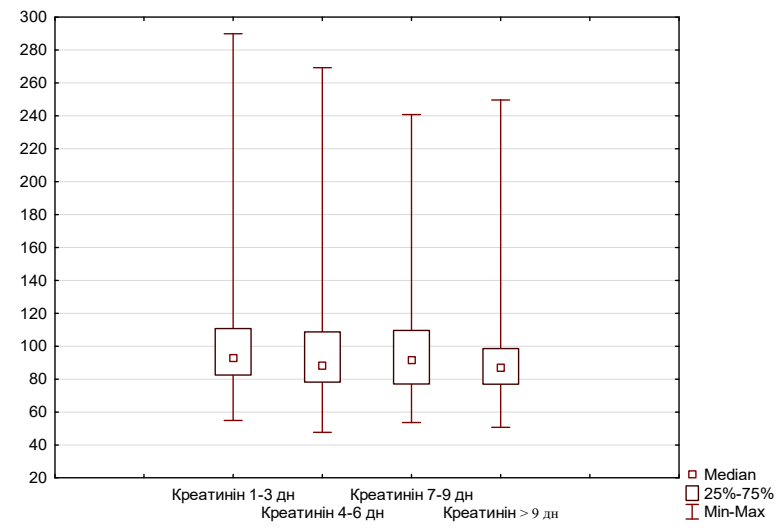

Динаміка рівня креатиніну у хворих, які одужали (мкмоль/л)

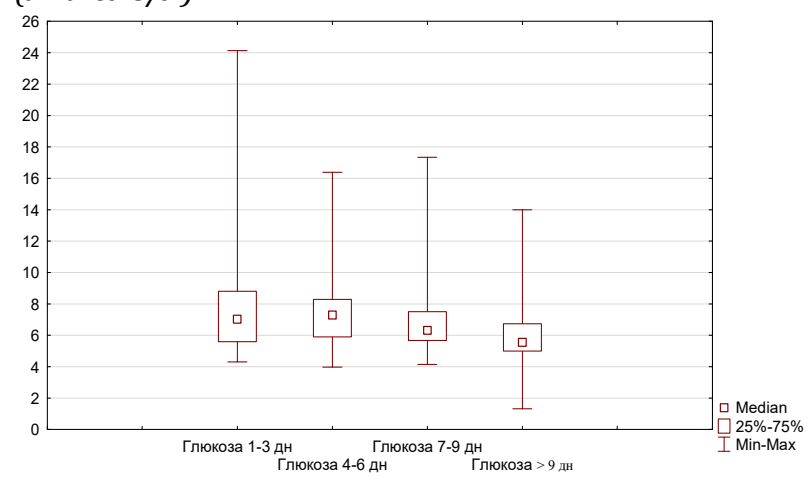

Динаміка рівня глюкози у хворих, які одужали (ммоль/л)

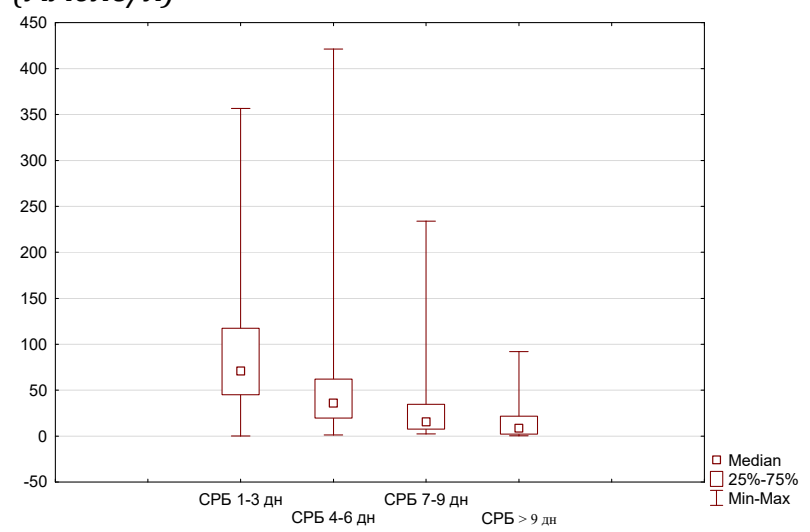

Динаміка рівня СРБ у хворих, які одужали (мг/л)

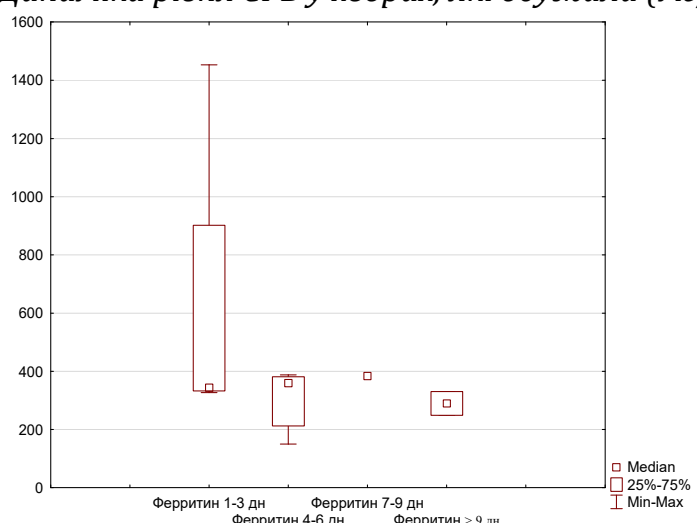

Динаміка рівня феритину у хворих, які одужали (нг/мл)

Рисунок 4. Динаміка рівня окремих біохімічних показників крові у хворих, які одужали або померли

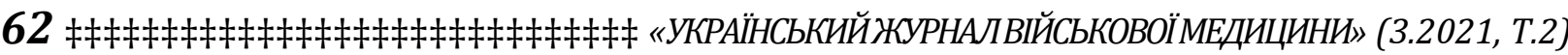

Динаміка рівня креатиніну у хворих, які померли (мкмоль/л)

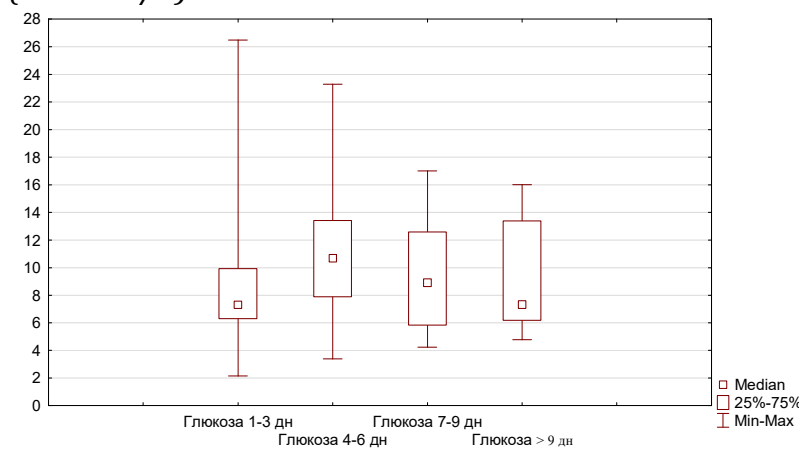

Динаміка рівня глюкози у хворих, які померли (ммоль/л)

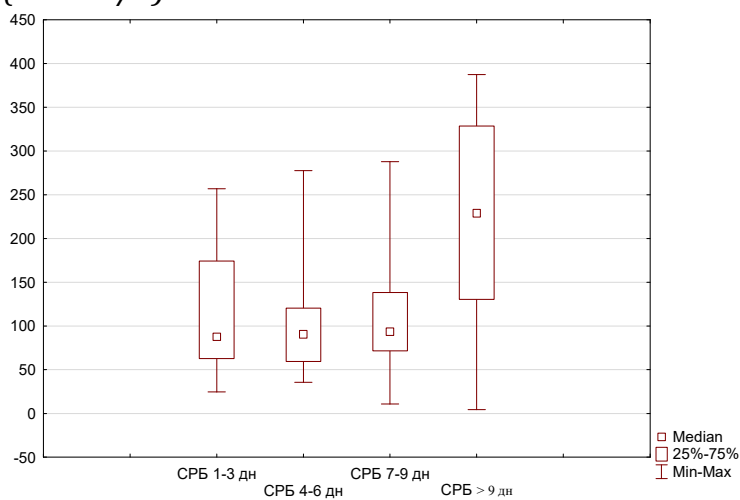

Динаміка рівня СРБ у хворих, які померли (мг/л)

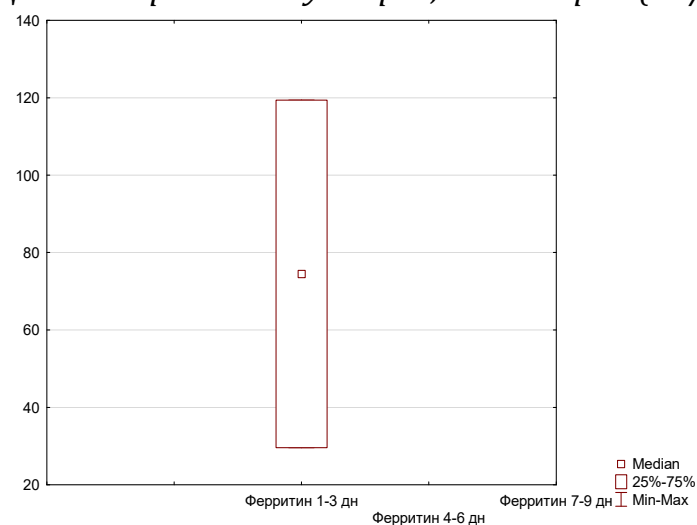

Рівень феритину у хворих які померли (нг/мл) 

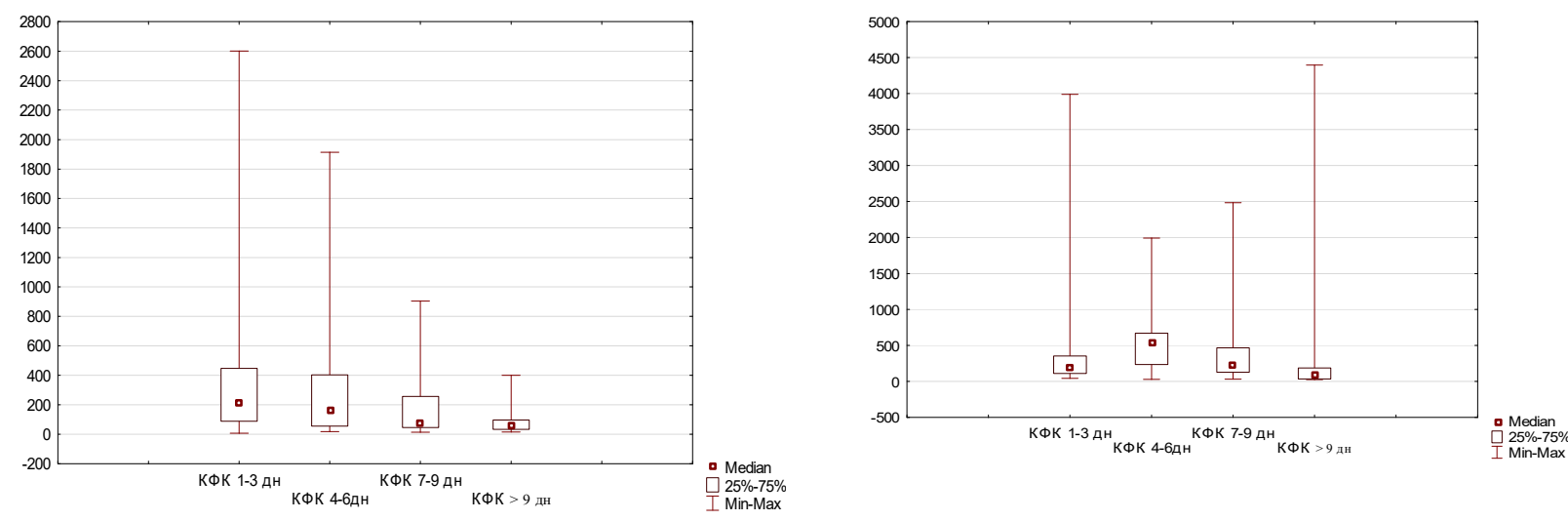

Динаміка рівня КФК ухворих, які одужали (Од/л)

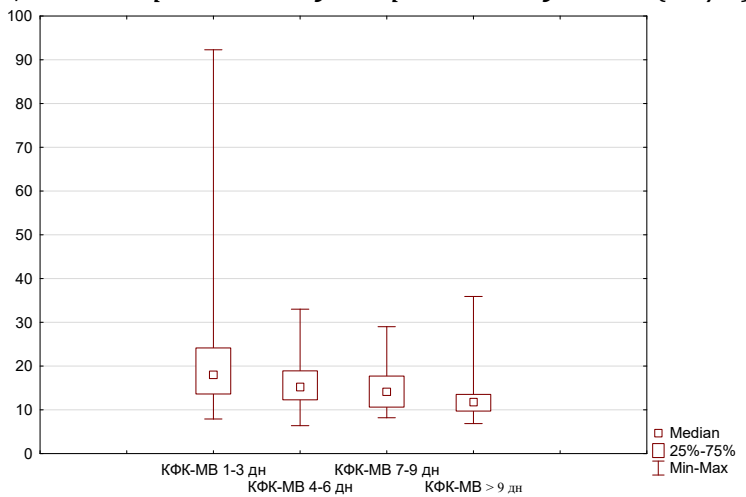

Динаміка рівня КВФ-МВ у хворих, які одужали $(O \partial / \Omega)$

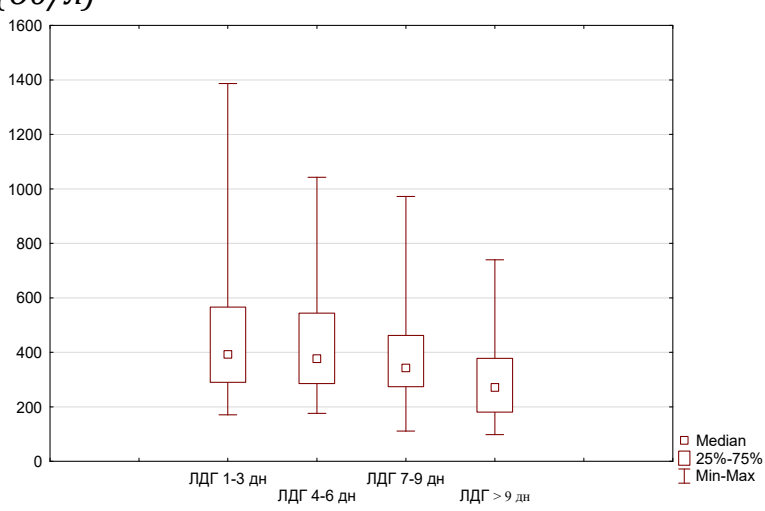

Динаміка рівня ЛДГу хворих, які одужали (Од/л)

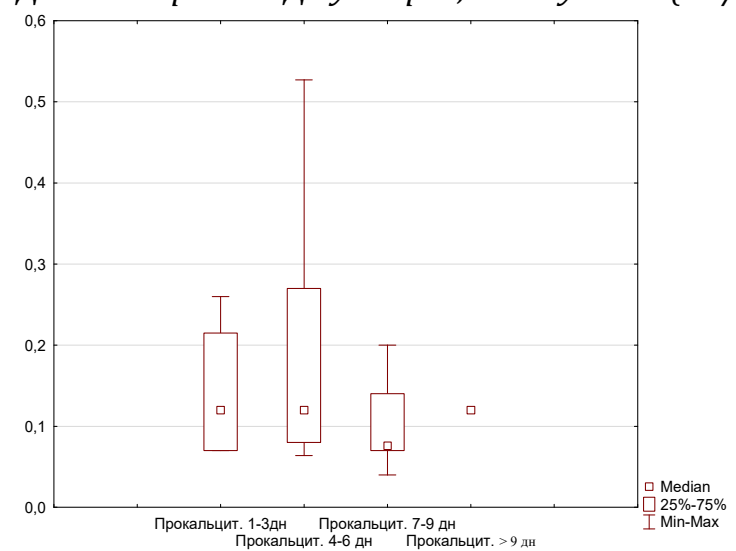

Динаміка рівня КФК у хворих, які померли (Од/л)

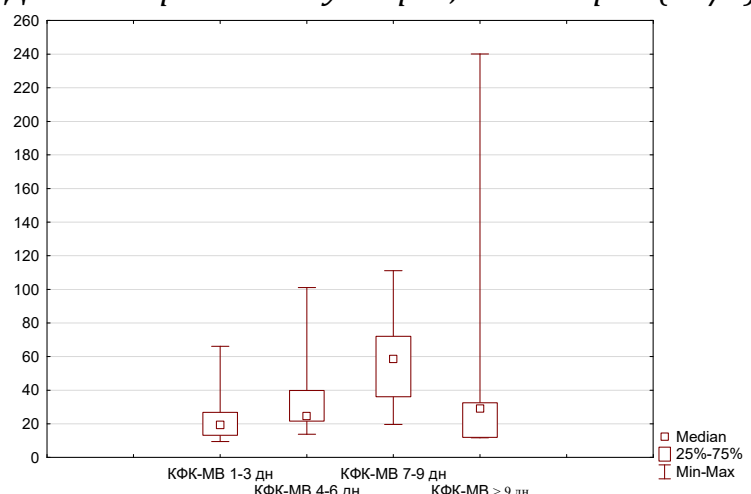

Динаміка рівня КФК-МВ у хворих, які померли $(0 \partial / \Omega)$

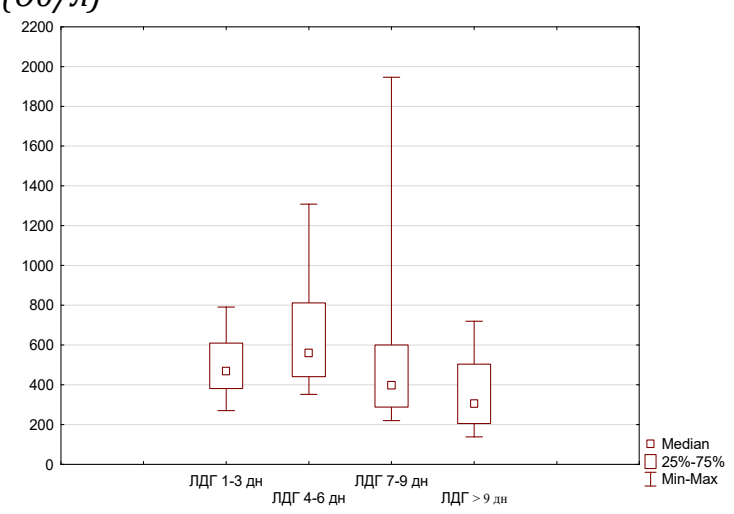

Динаміка рівня ЛДГ ухворих, які померли (Од/л)

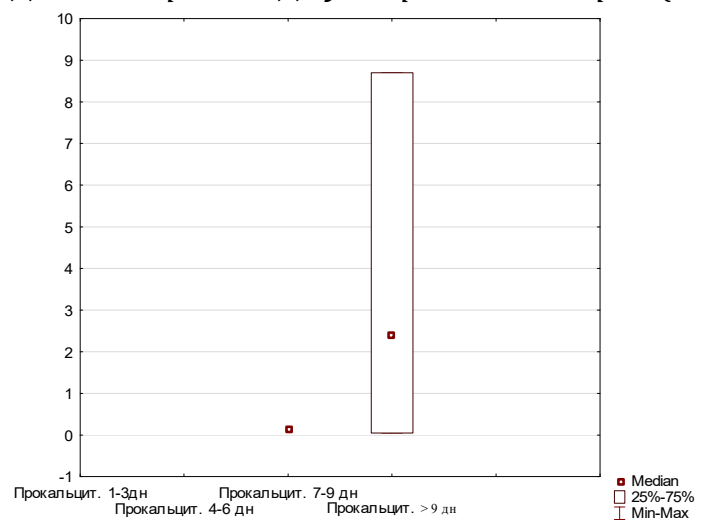

Динаміка рівня прокальцитоніну у хворих, які померли (нг/мл)

одужали (нг/мл)

них показників крові у хворих, які одужали або померли 
Рівень прокальцитоніну (рис. 5) у хворих, які одужали, незначно зростає з 4-ї доби більше 0,25 нг/мл і в наступному знижується, в той же

\section{Висновки}

1. Хворі, які померли в закладі охорони здоров'я, надходили раніше, ніж ті, хто одужали. Під час госпіталізації лабораторні показники можуть не відрізнятись у осіб, які одужають, або які помруть.

2. На початку госпіталізації більш знижені показники рівня лімфоцитів та вищі показники гранулоцитів, сечовини, креатиніну, СРБ можуть свідчити про несприятливий прогноз COVID-19.

3. Вже після 4 доби перебування у стаціонарі (5-11 доба хвороби) динаміка аналізів може

\section{References}

1. Roberto Assandri, Elisabetta Buscarini, Ciro Canetta et al. (2020). Laboratory Biomarkers Predicting COVID-19 Severity in the Emergency Room. Arch Med Res. Aug; 51(6): 598-599. [електронний ресурс] - Режим доступу: https://www.ncbi.nlm.nih.gov/pmc/articles/PMC724 1376/

2. Ali Pormohammad, Saied Ghorbani, Behzad Baradaran et al. (2020). Clinical characteristics, laboratory findings, radiographic signs and outcomes of 61,742 patients with confirmed COVID-19 infection: A systematic review and meta-analysis. Microb Pathog. 147: 104390. [електронний ресурс] - Режим доступу: час у хворих, які померли, після 9 доби його рівень зростає дуже високо.

свідчити про подальший перебіг хвороби та можливий наслідок (подальше зниження рівня лімфоцитів, збереження на високому рівні або зростання гранулоцитів, зростання паличкоядерних нейтрофілів, кількості тромбоцитів, ШОЕ, рівня сечовини, креатиніну, СРБ, прокальцитоніну, що свідчать про несприятливий наслідок).

\section{Перспективи подальших досліджень.}

Необхідно провести подальші дослідження стосовно характеру та терміну ураження нирок, серця, легень, стану мікроциркуляції та їх взаємозв'язку.

https://www.ncbi.nlm.nih.gov/pmc/articles/PMC736 7029/

3. Lakshmi Manoharan, Jonathan W. S. Cattrall, Carlyn Harris et al. (2021). Evaluating clinical characteristics studies produced early in the Covid-19 pandemic: A systematic review. PLoS; 16(5): e0251250. [електронний ресурс] - Режим доступу: https://www.ncbi.nlm.nih.gov/pmc/articles/PMC813 0955/

4. Dawei Wang, Bo Hu, Chang Hu et al. (2020). Clinical Characteristics of 138 Hospitalized Patients With 2019 Novel Coronavirus-Infected Pneumonia in Wuhan, China. JAMA. 2020 Mar 17; 323(11): 10611069. [електронний ресурс] - Режим доступу: https://www.ncbi.nlm.nih.gov/pmc/articles/PMC704 2881/

\section{КЛИНИКО-ЛАБОРАТОРНЫЕ ПОКАЗАТЕЛИ У БОЛЬНЫХ, ЛЕЧИВШИХСЯ В ОРИТ НВМКЦ «ГВКГ» ПО ПОВОДУ COVID-19}

\section{В.И. Трихлеб, Т.И. Лысенко, А.А. Ерошенко, А.С. Мартынчик}

Украинская военно-медицинская академия, г. Киев, Украина

Вступление. B статье представлен обзор литературы и результаты собственного обследования больных новой коронавирусной инфекцией COVID-19 с тяжелым течением.

Цель исследования. Установить особенности лабораторных показателей новой коронавирусной болезни COVID-19 у тяжелобольных, которые лечились в ОРИТ НВМКЦ «ГВКГ» в сезон активности грипп, поскольку было установлено ранее нами, что внебольничная пневмония в данный период года имеет более тяжелое течение.

Материалы и методы: обработаны данные 112 медицинских карт стационарного больного больных с тяжелым течением новой коронавирусной болезни COVID-19, которые лечились в ОРИТ НВМКЦ «ГВКГ» в период с января по апрель 2021 г.. Больных распределили следующим образом: первая группа - которые выздоровели, вторая - умершие. У всех пациентов была обнаружена пневмония с помощью рентгенографии органов грудной клетки или компьютерной томографии. У всех больных диагноз был подтвержден с помощью ПЦР в реальном времени с выявлением РHК SARS-COV-2. Статистическая обработка материалов исследования проводилась с помощью персонального компьютера с использованием программы STATISTICA. Была разработана анкета для ввода данных в программу Exсеl.

Результаты. Установлено, что при поступлении в реанимацию у больных, которые выздоровели, и умерших средние показатели уровня лейкоцитов существенно не отличались $(p>0,05)$. У тех, кто умер, в первые три дня после госпитализации наблюдались большие колебания уровня лейкоцитов. С 4 суток пребывания у тех, кто умер, наблюдались более высокие как средние показатели уровня лейкоцитов, также и их квартельные отклонения ( $Q_{25}$ и $\left.Q_{75}\right)$. При поступлении количество лимфоцитов было меньше у тех, кто 
умер, по сравнению с теми, кто выздоровел, но в последующие дни у первых наблюдалось дальнейшее их снижение или сохранение на низком уровне, в то же время у тех, кто выздоровел, сниженные показатели сохранялись практически на том же уровне и с 9 суток пребывания в стационаре наблюдалось их повышение ( $p<0,05$ по сравнению с теми, кто умер). Средний уровень гранулоцитов при поступлении был несколько выше у тех, кто в последующем умрет, и в дальнейшем их показатели увеличиваются, в то же время у тех, кто выздоровеет, показатели наоборот уже с 4-го дня постепенно снижаются. В первые три дня после госпитализации разницы в уровне палочкоядерных нейтрофилов между умершими и выздоровевшими не было ( $p>0,05)$, в то же время у тех, кто выздоровел, в последующем наблюдается уменьшение их количества, а у тех, кто умер, наоборот происходит их рост. В первые три дня разницы между количеством тромбоцитов между группами не было, в то же время у тех, кто умер с 9 суток наблюдаются более выраженные колебания их количества. Показатели СОЭ имели более выраженные колебания в первые три дня у тех, кто выздоровел и у них в последующем наблюдается уменьшение уровня СОЭ, в то же время у тех, кто умер, после 7 суток регистрируется их значительный рост. Показатели АлАТ, АсАТ повышались незначительно. В первые три дня после госпитализации у тех, кто умрет, наблюдались несколько более высокие показатели уровня мочевины, по сравнению с теми, кто выздоровел (p>0,05). В обеих группах больных в последующие дни наблюдается увеличение уровня мочевины, но у тех, кто умрет, было увеличение до более высоких значений. Также и в отношении показателей креатинина, которые были больше уже в начале госпитализации и после 7 суток регистрировались более выраженные колебания у умерших, чем у тех, кто выздоровел. В обеих группах больных уже сразу после госпитализации регистрировались повышенные показатели уровня глюкозы (р>0,05). У тех, кто выздоровел, наблюдается постепенное снижение уровня глюкозы, а у тех, кто умер, после 4 суток их наоборот наблюдался еще больший рост. Сразу после госпитализации у тех, кто умрет, показатели СРБ были несколько больще по сравнению с теми, кто выздоровеет, но в последующем уже с 4-го дня у тех, кто умрет, регистрируется их дальнейший рост, а у тех, кто выздоровит, наоборот их уменьшение ( $p<0,05)$.

Выводы. Больные, которые в последующем умерли, поступали раньше, чем те, кто выздоровили. Во время госпитализации лабораторные показатели могут не отличаться улиц, которые поправятся, и у тех, кто умрет. В начале госпитализации более сниженные показатели уровня лимфоцитов и высокие показатели гранулоцитов, мочевины, креатинина, СРБ могут свидетельствовать о неблагоприятном результате. Уже после 4 суток пребывания в стационаре (5-11 сутки болезни) динамика анализов может свидетельствовать о дальнейшем течении болезни и возможных последствиях (снижение уровня лимфоцитов, сохранение на высоком уровне или рост гранулоцитов, рост палочкоядерных нейтрофилов, количества тромбоцитов, СОЭ, уровня мочевины, креатинина, СРБ, прокальцитонина - свидетельствуют о неблагоприятном исходе). Необходимо провести дальнейшие исследования относительно характера и срока поражения почек, сердца, легких, состояния микроциркуляции и их взаимосвязи.

Ключевые слова: COVID-19, тяжелобольные, лабораторные показатели.

\section{CLINICAL AND LABORATORY PARAMETERS IN COVID-19 PATIENTS TREATED AT THE NMMCC 'MMCH'}

\section{V.I. Trykhlib, T.I. Lysenko, A.A. Yeroshenko, A.S. Martynchyk}

Ukrainian Military Medical Academy, Kyiv, Ukraine

Introduction. The article presents a review of the literature and the results of our own examination of patients with new coronavirus infection COVID-19 with a severe course.

The purpose. To establish the features of laboratory indicators of the new coronavirus disease COVID-19 in seriously ill patients, who were treated in the ICU of the NMMCC 'MMCH' during the season of influenza activity due to previously found that community-acquired pneumonia in this period of the year has a more severe course.

Materials and methods The data of 112 medical records of an inpatient patients with a severe course of the new coronavirus disease COVID-19 were processed, who were treated in the ICU of the NMMCC 'MMCH' in the period from January to April 2021. The patients were distributed as follows: the first group - who recovered, the second - who died. All patients were diagnosed with pneumonia by chest $x$-ray or computed tomography. In all patients the diagnosis was confirmed by real-time PCR with the detection of SARS-COV-2 RNA. Statistical processing of research materials was carried out using a personal computer using the STATISTICA program. A questionnaire was developed for entering data into Excel.

Results. It was found that upon admission to the intensive care unit in patients who recovered and those who died, the mean leukocyte counts did not differ significantly $(p>0.05)$. Those who died had large fluctuations in leukocyte levels during the first three days after admission. From the 4th day of stay, those who died had higher both average leukocyte counts and their quartile deviations (Q25 and Q75). On admission the number of lymphocytes was lower in those who died compared to those who recovered, but in the following days the former were further reduced or kept at a low level, while those who recovered had lowered numbers remaining at almost the same level and from day 9 of stay in hospital an increase was observed ( $p<0.05$ compared to those who died). The average level of granulocytes at admission was slightly higher in those who subsequently died, and subsequently their values increased, while those who recovered, on the contrary, values gradually decreased from the 4th day. In the first three days after hospitalization there was no difference in the level of stab neutrophils between those who died and those who recovered ( $p>0,05)$, while those who recovered subsequently have a decrease in their number, and those who died, on the contrary, have an increase. In 
the first three days there was no difference in the number of platelets between the groups, while those who died from day 9 had more pronounced fluctuations in their number. SLE indicators had more pronounced fluctuations in the first three days in those who recovered, and they subsequently showed a decrease in the level of SLE, while those who died after 7 days recorded a significant increase. AlT, AsT increased insignificantly. In the first three days after hospitalization, those who died had slightly higher urea levels compared to those who recovered ( $p>0.05)$. In both groups of patients, there was an increase in urea levels in the following days, but those who died had an increase to higher values. Also with regard to creatinine values, which were higher already at the beginning of hospitalization and after 7 days more pronounced fluctuations were registered in those who died than in those who recovered. In both groups of patients, elevated glucose levels were registered immediately after hospitalization ( $p>0.05)$. In those who recovered, there was a gradual decrease in glucose levels, and in those who died, on the contrary, there was an even greater increase after 4 days. Immediately after hospitalization, those who died had slightly higher CRP levels compared to those who recovered, but subsequently, from day 4, those who died registered a further increase, while those who recovered, on the contrary, decreased ( $p<0.05)$.

Conclusions. Patients who subsequently died were admitted earlier than those who recovered. During hospitalization, laboratory values may not differ between individuals who recover and those who die. At the beginning of hospitalization, more reduced levels of lymphocytes and high levels of granulocytes, urea, creatinine, CRP may indicate an unfavorable result. Already after 4 days of hospitalization (5-11 days of illness), the dynamics of the tests may indicate the further course of the disease and possible consequences (a decrease in the level of lymphocytes, the persistence of a high level or growth of granulocytes, the growth of stab neutrophils, the number of platelets, ESR, the level of urea, creatinine, CRP, procalcitonin - indicate an unfavorable outcome). Further research is needed on the nature and timing of kidney, heart, lung damage, microcirculation and their relationship.

Key words: COVID-19, seriously ill, laboratory parameters.

Конфлікт інтересів: відсутній.

Conflicts of interest: authors have no conflict of interest to declare.

Відомості про авторів:

Трихліб В.І.А,B,D,E,F - доктор медичних наук, професор, професор кафедри військової терапії Української військово-медичної академії, м. Київ

Київ

Лисенко T.I. ${ }^{\mathrm{BC}, \mathrm{D}}$ - лейтенант медичної служби, слухач Української військово-медичної академії, м.

Єрошенко А.о. В,С,D - лейтенант медичної служби, слухач Української військово-медичної академії, м.

Київ

Мартинчик О.C. B,C,D - лейтенант медичної служби, слухач Української військово-медичної академії, м. Київ

$A$ - концепція та дизайн дослідження; $B$ - збір даних; $C$ - аналіз та інтерпретація даних;

$D$ - написання статmi; $E$ - редагування статmi; F- остаточне затвердження статті.

\section{Сведения об авторах:}

Трихлеб В.И. - доктор медицинских наук, профессор кафедры военной терапии Украинской военномедицинской академии, г. Киев

Лысенко Т.И. - лейтенант медицинской службы, слушатель Украинской военно-медицинской академии, г. Киев

Ерошенко А.А. - лейтенант медицинской службы, слушатель Украинской военно-медицинской академии, г. Киев

Мартинчик А.С. - лейтенант медицинской службы, слушатель Украинской военно-медицинской академии, г. Киев

Information about the authors:

Trykhlib V.I. A, B, D, E, F - retired Colonel of the medical service, Doctor of Medical Sciences, Professor, Professor of the Department of Military Therapy of the Ukrainian Military Medical Academy, Kyiv. https://orcid.org/00000001-9250-4385

Lysenko T.I. V, C, D - Lt MS, student of the Ukrainian Military Medical Academy, Kyiv

Yeroshenko A.A. B, C, D - Lt MS, student of the Ukrainian Military Medical Academy, Kyiv

Martynchyk A.S. B, C, D - Lt MS, student of the Ukrainian Military Medical Academy, Kyiv

$A$ - research concept and design; $B$ - collection and/or assembly of data; $C$ - data analysis and interpretation;

$D$ - writing the article; $E$ - critical revision of the article; $F$ - final approval of the article.

Адреса для листування: вул. Московська, 45/1, буд. 33, м. Київ 01015 